of head, not reaching origin of anal. Caudal rounded. Caudal peduncle as long as deep. Scales denticulate, 36-39 $\frac{6-7}{15-18}$; lateral lines 21-24/13-17. Brownish above, yellowish beneath, with dark brown spots or marblings or with 7 or 8 indistinct dark bars on the body; a blackish opercular spot; dorsal, anal, and caudal fins with round brown or blackish spots.

Total length $160 \mathrm{~mm}$.

Several specimens were obtained by Dr. Ansorge. A specimen measuring $215 \mathrm{~mm}$., from the Zambesi, has been submitted to me by Dr. J. D. F. Gilchrist.

Closely allied to P. robusta, Gthr.

XX.-Description of a new Frog discovered by Dr. W.J. Ansorge in Mossamedes, Angola. By G. A. Boulenger, F.R.S.

\title{
Rana cryptotis.
}

Tongue rather feebly notched behind. Vomerine teeth in two oblique groups between the choanæ. Habit very stout. Head short, snout rounded; interorbital space narrower than the upper eyelid; tympanum completely hidden under the skin. Fingers short, pointed, first and second equal; toes short, one-third webbed; subarticular tubercles of toes very prominent, conical; inner metatarsal tubercle very large, very prominent, shovel-shaped, sharp-edged, at least as long as the inner toe ; a small, round, outer metatarsal tubercle; a round tarsal tubercle, just below the tibio-tarsal articulation. The tarso-metatarsal articulation reaches the eye. Skin smooth. Pale greyish or brownish above, with dark-edged grey or brown spots disposed with greater or less symmetry; an interrupted dark cross-bar between the eyes ; back sometimes with white or pink dots; a light vertebral streak often present; hind limbs with dark transverse spots, not forming complete cross-bars; lower parts white.

From snout to vent $31 \mathrm{~mm}$.

Numerous specimens were obtained by Dr. Ansorge at Catequero, Ponang Kuma (Dongwenna), and in the Kafitu Swamps.

The hidden tympanum and the tarsal tubercle well distinguish this small frog from $R$. Delalandii and other allied species from Africa. 


\section{$2 \mathrm{BHL}$ Biodiversity Heritage Library}

Boulenger, George-Albert. 1907. "XX.-Description of a new frog discovered by Dr. W. J. Ansorge in Mossamedes, Angola." The Annals and magazine of natural history; zoology, botany, and geology 20, 109-109.

https://doi.org/10.1080/00222930709487312.

View This Item Online: $\underline{\text { https://www.biodiversitylibrary.org/item/85040 }}$

DOI: https://doi.org/10.1080/00222930709487312

Permalink: https://www.biodiversitylibrary.org/partpdf/64133

\section{Holding Institution}

Smithsonian Libraries

\section{Sponsored by}

Smithsonian

\section{Copyright \& Reuse}

Copyright Status: Public domain. The BHL considers that this work is no longer under copyright protection.

This document was created from content at the Biodiversity Heritage Library, the world's largest open access digital library for biodiversity literature and archives. Visit BHL at https://www.biodiversitylibrary.org. 